\title{
Socio-demographics and asthma prevalence, management, and outcomes among children 1-11 years of age in California
}

\author{
Jim E. Banta ${ }^{1 *}$, Majed Ramadan ${ }^{1}$, Noara Alhusseini ${ }^{2}$, Khaled Aloraini $^{1}$ and Naomi Modeste ${ }^{1}$
}

\begin{abstract}
Background: Asthma disproportionately affects minority and low-income children. We examined asthma prevalence, management and outcomes, focusing on race/ethnicity and acculturation of parents (particularly English language proficiency).

Methods: This cross-sectional, correlational analysis used a de-identified population-based survey, the California Health Interview Survey, for years 2001-2015. Survey-weighted analysis with SAS 9.4 was used to determine asthma prevalence among children 1 to 11 years of age. Descriptive analysis was conducted, adjusting for survey design and combination of multiple years of data. The Pearson test, using design-based $F$ values was used to determine statistically significant differences between those having/not having a doctor diagnosis of asthma. Multivariable logistic regression, with jackknife approach to obtain confidence intervals, was used to examine associations of child and parental characteristics with asthma prevalence, management, and outcomes.

Results: The 61,625 completed surveys represented an estimated annual population of 5.7 million children, of which $12.9 \%$ had asthma. There were significant $(p<0.001)$ differences by age, gender, race, and language proficiency, with higher asthma prevalence for children 6 to 11 years of age (15.5\%), males (15.3\%), African Americans (19.5\%), and parents speaking English very well (14.1\%). Compared to children whose parents spoke English very well, those whose parents spoke English not well or not at all were less likely to achieve optimal asthma management, i.e. to have received a management plan from doctor (OR 0.30; $95 \%$ Confidence Interval $0.20-0.46)$ ), to be currently taking medication to control asthma (OR 0.52; $95 \% \mathrm{Cl} 0.36-0.74)$ ), or to be not confident in ability to control asthma (OR 3.10; $95 \% \mathrm{Cl}$ 1.49-6.42). Children whose parents spoke English fairly well rather than very well had worse outcomes, i.e. were more likely to have an emergency room visit in past 12 months (OR 1.92; $95 \% \mathrm{Cl} 1.03-3.61$ ) and were more likely to miss school due to asthma in past 12 months (OR 0.71; 1.01-2.94).
\end{abstract}

Conclusions: Socio-demographics had a limited role in explaining differences across a handful of asthma management and outcome measures in California. Parental English language proficiency had the most consistent influence, underscoring the need for culturally and linguistically competent care.

Keywords: Children, Ethnic groups, Parents, Asthma, Cross-sectional studies, Surveys and Questionnaires, Language, California

\footnotetext{
* Correspondence: jbanta@llu.edu

'Loma Linda University School of Public Health, 24951 Circle Dr, CA 92354

Loma Linda, USA

Full list of author information is available at the end of the article
}

(c) The Author(s). 2021 Open Access This article is licensed under a Creative Commons Attribution 4.0 International License, which permits use, sharing, adaptation, distribution and reproduction in any medium or format, as long as you give appropriate credit to the original author(s) and the source, provide a link to the Creative Commons licence, and indicate if changes were made. The images or other third party material in this article are included in the article's Creative Commons licence, unless indicated otherwise in a credit line to the material. If material is not included in the article's Creative Commons licence and your intended use is not permitted by statutory regulation or exceeds the permitted use, you will need to obtain permission directly from the copyright holder. To view a copy of this licence, visit http://creativecommons.org/licenses/by/4.0/. 


\section{Background}

Asthma is a leading chronic disease among children in the United States [1], with prevalence being higher among boys (9.2\%) than among girls (7.4\%) [2]. Prevalence is higher among minorities [3], particularly among non-Hispanic African American/Black children (15.7\%) compared to white children (7.1\%) [2]. Uncontrolled asthma symptoms can lead to serious complications ranging from sleep disturbance [4] to death [5]; thus, the imperative to address determinants of asthma burden among children [6]. A recent CDC study found that $51 \%$ of children in school with current asthma missed at least one school day as a result of asthma in the prior 12 months [7]. Asthma, particularly poor asthma control, is associated with more emergency department (ED) visits [8] and increased hospitalization. Health care expenditures in the United States are estimated to be $\$ 5.92$ billion for treatment among school-aged children with asthma, which represents an extra \$847 expenditures per child as a result of asthma [9].

Asthma in children is the result of complex geneenvironment interactions, with some risk factors including sex (boys), parental history of asthma, and personal history of allergy [10, 11]. Additional risk factors for asthma include air pollution, psychosocial stress, obesity and inadequate treatment $[12,13]$. Barriers to receiving adequate treatment include economic disadvantages, lack of education, limited or lack of health insurance plans and poor access to medication [13]. Asthma is more common among children and families below poverty level [14]. There is a significant association between air pollution and impaired lung functions among minorities with asthma [15]. Furthermore, childhood asthma is more common within public housing compared to private housing due to multiple housing quality factors [16].

Children with asthma report cost barriers to healthcare services such as the inability to afford medication and see a primary physician. A California study found that $30 \%$ of asthma control prescriptions prescribed to low-income children were never filled [17]. A related barrier is lack of health care insurance [13] or public insurance, particularly among Latino children [18].In a study of children having the same access to healthcare, Black and Hispanic children were more likely to have avoidable hospitalizations, asthma-related ED visits, and less likely to visit a specialist compared to white children [19]. Black, Hispanic, and low-income children with asthma are more likely to not have a usual source for medical care and more likely to use EDs than are white children [20].

Adverse asthma outcomes can be managed by controlling environmental measures, increased patient education and medication [17]. Furthermore, care coordination, selfmanagement education and patient-centered approaches play a vital role in controlling asthma and limiting healthcare utilization [21]. Barriers that limit participation in asthma management programs include poverty, language barriers, lack of insurance, and difficulty in arranging transportation to physicians' clinics [22]. Using alternative medicine and home remedies among minority groups can alter the effectiveness of medication, interact with treatment outcomes and cause a harmful effect [23].

The goal of this study was to examine asthma prevalence, management, and outcomes among California children. Of particular interest is examining the influence of race/ethnicity and acculturation-related measures with respect to asthma prevalence, management, and outcomes.

\section{Methods}

Data Source

The California Health Interview Survey (CHIS) is considered to be the largest state health survey in the nation [24]. It began as a biennial population-based survey in 2001 and is collaboratively facilitated by the University of California, Los Angeles Center for Health Policy Research and other state agencies. It is conducted in languages such as English, Spanish, Cantonese, Mandarin, Korean, and Vietnamese [25]. Public-use files are released for children (0-11 years of age), adolescents (1217 years of age), and adults (18 years of age and greater).

There were nine different public-use data survey files, which were downloaded directly from the UCLA website and combined for this analysis. CHIS initially released data in two-year increments, switching to one-year data files in 2013. Different weighting variables were used for each survey year, and survey year was included as a covariate in all multivariable regressions. Though many questions were asked consistently throughout the study period, there were also changes over time. Thus not all years of data were used for some analysis of outcomes. Sometimes there were differences in how data was reported. For example, parental education had slightly different levels of detail depending on survey year. However, after recoding to fewer groups, there was equivalence over time.

\section{Sample}

CHIS is a population-based telephone survey that uses a random-digit-dial sample for both landlines and cell phones, with the landline sample segregated into 56 geographic sampling strata, corresponding to county boundaries within the state. From each stratum, residential telephone numbers were selected to interview an adult. If the household included a child or adolescent, the adult was also asked questions about that child and/or adolescent. If there were multiple children or adolescents, CHIS randomly selected one for survey purposes. The 
Table 1 Survey-weighted characteristics of Hispanic and White California children, 2001 to 2015

\begin{tabular}{|c|c|c|c|c|}
\hline & $\begin{array}{l}\text { Total } \mathbf{n} \\
\text { (percent) }\end{array}$ & $\begin{array}{l}\text { Percent with Asthma, } \\
\mathrm{Cl}\end{array}$ & $\begin{array}{l}\text { Asthma } P \text { - } \\
\text { value }\end{array}$ & \\
\hline & $61,625(100 \%)$ & $12.9(12.3,13.4)$ & & \\
\hline Age & & & $<0.001$ & $* * *$ \\
\hline 1 to 5 years & $26,856(45.2 \%)$ & $9.7(8.9,10.4)$ & & \\
\hline 6 to 11 years & $34,769(54.8 \%)$ & $15.5(14.7,16.4)$ & & \\
\hline Gender & & & $<0.001$ & *** \\
\hline Male & $31,684 \quad(51.0 \%)$ & $15.3(14.5,16.1)$ & & \\
\hline Female & $29,941(49.0 \%)$ & $10.4(9.5,11.1)$ & & \\
\hline Race/ethnicity & & & $<0.001$ & $* * *$ \\
\hline Hispanic & $18,764(42.1 \%)$ & $12.4(11.3,13.5)$ & & \\
\hline Asian & $6,627(10.7 \%)$ & $12.9(10.8,14.9)$ & & \\
\hline African American & $2,801(6.6 \%)$ & $19.5(16.8,22.2)$ & & \\
\hline White & $29,979(34.5 \%)$ & $12.0(11.3,12.8)$ & & \\
\hline Two or more Races & $4,454(6.2 \%)$ & $13.7(11.3,16.1)$ & & \\
\hline Adult English Proficiency & & & $<0.001$ & $* * *$ \\
\hline Very well & $43,953(66 / 2 \%)$ & $14.1(13.2,14.9)$ & & \\
\hline Fairly well & $6,349(12.4 \%)$ & $11.9(9.9,14.0)$ & & \\
\hline Not well / Not at all & $11,323(21.4 \%)$ & $9.7(8.6,10.8)$ & & \\
\hline Adult Education & & & $<0.001$ & $* * *$ \\
\hline Less than 12 years education & $10,443(21.4 \%)$ & $11.0(9.9,12.1)$ & & \\
\hline High School graduate & $13,247(22.4 \%)$ & $13.4(11.9,14.9)$ & & \\
\hline Less than 4 years college & $14,369(22.2 \%)$ & $16.1(14.7,17.5)$ & & \\
\hline College graduate or higher & $23,568(34.1 \%)$ & $11.4(10.5,12.3)$ & & \\
\hline Poverty level & & & 0.6217 & \\
\hline 0-99\% FPL & 10,389 (24.0\%) & $13.3(11.8,14.8)$ & & \\
\hline 100-199\% FPL & $12,460(22.5 \%)$ & $13.2(11.9,14.4)$ & & \\
\hline 200-299\% FPL & 8,635 (13.7\%) & $13.1(11.5,14.7)$ & & \\
\hline $300 \% \mathrm{FPL}$ and Above & $30,141(39.8 \%)$ & $12.4(11.6,13.2)$ & & \\
\hline Living environment & & & 0.0680 & \\
\hline Urban & $50,563(89.2 \%)$ & $13.0(12.4,13.7)$ & & \\
\hline Rural & $11,064(10.8 \%)$ & $11.5(10.1,12.9)$ & & \\
\hline Usual Source of Care & & & 0.0045 & ** \\
\hline Doctor office/HMO/Kaiser & $45,244(69.2 \%)$ & $13.3(12.6,14.0)$ & & \\
\hline $\begin{array}{l}\text { Community/Government } \\
\text { clinic }\end{array}$ & $14,208(22.7 \%)$ & $12.5(11.2,13.7)$ & & \\
\hline ER/Urgent care/ Other place & $550(1.0 \%)$ & $12.6(8.1,17.1)$ & & \\
\hline No usual source of care & $1,623(3.1 \%)$ & $7.4(5.0,9.8)$ & & \\
\hline Insurance status & & & 0.0222 & * \\
\hline Insured & $58,430(95.1 \%)$ & $13.0(12.4,13.6)$ & & \\
\hline Not insured & $3,195(4.9 \%)$ & $9.8(7.3,12.2)$ & & \\
\hline Citizenship Status & & & $<0.001$ & $* * *$ \\
\hline US-born citizen & $38,019(55.7 \%)$ & $14.2(13.3,15.0)$ & & \\
\hline Naturalized citizen & $10,014(17.4 \%)$ & $12.2(10.8,13.7)$ & & \\
\hline Non-Citizen & 13,592 (26.7\%) & $10.6(9.5,11.7)$ & & \\
\hline
\end{tabular}


Table 1 Survey-weighted characteristics of Hispanic and White California children, 2001 to 2015 (Continued)

\begin{tabular}{llll}
\hline & $\begin{array}{l}\text { Total } \mathbf{n} \\
\text { (percent) }\end{array}$ & $\begin{array}{l}\text { Percent with Asthma, } \\
\text { Cl }\end{array}$ & $\begin{array}{l}\text { Asthma } \text { - } \\
\text { value }\end{array}$ \\
\hline $2001-2002$ & $11,794(11.2 \%)$ & $12.7(12.0,13.5)$ \\
$2003-2004$ & $7,863(11.2 \%)$ & $13.7(12.7,14.8)$ \\
$2005-2006$ & $10,403(11.4 \%)$ & $13.5(12.4,14.6)$ \\
$2007-2008$ & $9,134(11.5 \%)$ & $13.5(12.4,14.5)$ \\
$2009-2010$ & $8,343(11.5 \%)$ & $11.2(10.8,12.2)$ \\
$2011-2012$ & $6,879(10.9 \%)$ & $14.2(12.7,15.7)$ \\
2013 & $2,763(10.7 \%)$ & $13.6(11.2,15.9)$ \\
2014 & $2,457(10.8 \%)$ & $12.0(9.4,14.6)$ \\
2015 & $1,989(10.9 \%)$ & $11.5(8.4,14.6)$ \\
\hline
\end{tabular}

Estimated annual population of children $=5,697,515$. Those with asthma $=733,320$. Sample numbers are unweighted, all percents are survey-weighted Cl 95\% Confidence Interval

${ }^{*} p<0.05,{ }^{* *} p<0.01,{ }^{* * *} p<0.001$

sampling design began including cell phones in 2009, with percentages steadily increasing over time. For example in CHIS 2013-2014, $19.3 \%$ of adult surveys were conducted using cell phones, compared to $46.2 \%$ in CHIS 2015[26]. Survey completion rates from CHIS are comparable to other large-scale surveys, such as the California Behavioral Risk Factor Surveillance System [27]. In 2009, the screening completion rate of all households was $35.1 \%$ and the child extended survey completion rate was 72.9 , for a survey completion rate of $26.3 \%$ for child surveys [27]. As a result of the sampling design, users are able to make population estimates. Researchers have demonstrated that CHIS population estimates are consistent with California's official demographic estimates when stratified by a number of demographic characteristics, including gender, race/ethnicity, and age group [28]. For this study we examined children data for 2001-2015, dropping infants (0 years of age) from analysis since their parents were not asked about many health topics.

\section{Measures}

Asthma prevalence was determined by the question "Have you ever been told by a physician that you have asthma?" Subsequent analyses were restricted to those reporting 'yes'. Asthma management measures included taking daily medication to control asthma (yes/no), doctor ever give management plan for child (yes/no), have a written copy of a plan (yes/no), and confidence to control asthma (yes/ no). Asthma outcome measures were: asthma attacks last 12 months [numeric, recoded (yes/no)], emergency department visits last 12 months - for any reason [numeric, recoded (yes/no)], and missed school due to asthma in last 12 months (yes/no). Not all asthma-related questions were asked during every survey year.

There were two measures of acculturation. One was citizenship status of father (US born, naturalized, and undocumented immigrant). The other was language, as it has been identified in the literature as a rational proxy for acculturation for Latinos [29]. Adult level of English proficiency was self-reported as very well, fairly well and not well / not at all (the last two combined by authors). English language proficiency has been used in national surveys to study access to care [30].

Demographics included age of child (categorized for this study as $0-5$, and $6-11$ years), gender of child, and race/ethnicity of child (white, Latino, Black, Asian, and "other", which included "Native Hawaiian" and "Two or more races"). Socioeconomic status was assessed based on education level and poverty level using CHIS variables of (a) adult education attainment categorized as an ordinal scale and (b) poverty level (ordinal scale). Geographic location was based on respondent zip code and categorized by UCLA into urban or rural. Healthcare access measures included: (a) usual source of care (ordinal) and (b) any insurance in the last 12 months (nominal as provided by CHIS).

\section{Data Analysis}

All data analyses were conducted using SAS 9.4 software (SAS Institute, Cary, NC). Descriptive analysis was conducted to obtain frequencies for all variables, adjusting for survey design and combination of multiple years of data. The Pearson test, using design-based F values, for categorical variables was used to determine statistical significant differences between each category. To analyze the association between race and acculturation with asthma prevalence and outcomes, multivariable logistic regression was conducted, and a jackknife approach used to obtain confidence intervals. The jackknife approach to variance estimation is preferred for CHIS data since they provide 80 replicated weights per survey year in order to ensure that the sampled data best matches the California population [31]. Asthma management and 
Table 2 Logistic Regression for asthma diagnosis $(n=61,625)$

\begin{tabular}{|c|c|c|c|}
\hline & \multicolumn{2}{|c|}{ Doctor Ever Told you Your Child has Asthma } & \multirow[b]{2}{*}{$P$-value } \\
\hline & OR & $95 \% \mathrm{Cl}$ & \\
\hline \multicolumn{4}{|l|}{ Age } \\
\hline 1 to 5 years (ref.) & --- & --- & \\
\hline 6 to 11 years & $1.78^{* * *}$ & $(1.60,1.99)$ & $<0.001$ \\
\hline \multicolumn{4}{|l|}{ Gender } \\
\hline Male (ref.) & --- & --- & \\
\hline Female & $0.63^{* * *}$ & $(0.57,0.70)$ & $<0.001$ \\
\hline \multicolumn{4}{|l|}{ Race/ethnicity } \\
\hline Hispanic (ref.) & --- & --- & \\
\hline Asian & 1.06 & $(0.85,1.32)$ & 0.595 \\
\hline African American & $1.17^{*}$ & $(1.02,1.50)$ & 0.299 \\
\hline White & $0.68^{* * *}$ & $(0.61,0.75)$ & $<0.001$ \\
\hline Two or more Races & 0.93 & $(0.59,0.79)$ & 0.634 \\
\hline \multicolumn{4}{|l|}{ Adult English Proficiency } \\
\hline Very well (ref.) & --- & --- & \\
\hline Fairly well & $0.78^{*}$ & $(0.61,1.02)$ & 0.047 \\
\hline Not well / Not at all & $0.60^{* * *}$ & $(0.48,0.77)$ & $<0.001$ \\
\hline \multicolumn{4}{|l|}{ Adult Education } \\
\hline Less than 12 years (ref) & --- & -- & \\
\hline High School graduate & 1.04 & $(0.86,1.26)$ & 0.682 \\
\hline Some college & $1.21^{*}$ & $(1.00,1.46)$ & 0.045 \\
\hline College graduate or higher & 0.91 & $(0.74,1.11)$ & 0.356 \\
\hline \multicolumn{4}{|l|}{ Poverty level } \\
\hline 0-99\% FPL (ref.) & --- & --- & \\
\hline 100-199\% FPL & 0.85 & $(0.71,1.04)$ & 0.159 \\
\hline $200-299 \%$ FPL & $0.77^{*}$ & $(0.61,0.96)$ & 0.021 \\
\hline $300 \% \mathrm{FPL}$ and Above & $0.74^{* *}$ & $(0.55,0.83)$ & 0.005 \\
\hline \multicolumn{4}{|l|}{ Living environment } \\
\hline Urban (ref.) & --- & --- & \\
\hline Rural & 0.85 & $(0.74,0.99)$ & 0.038 \\
\hline \multicolumn{4}{|l|}{ Usual Source of Care } \\
\hline Office/HMO/Kaiser (ref.) & --- & --- & \\
\hline Government/community & 1.00 & $(0.86,1.16)$ & 0.964 \\
\hline ER/Urgent care/ Other place & 0.88 & $(0.55,1.42)$ & 0.582 \\
\hline No usual source of care & $0.57^{* *}$ & $(0.40,0.84)$ & 0.004 \\
\hline \multicolumn{4}{|l|}{ Insurance status } \\
\hline Insured (ref.) & -- & --- & \\
\hline Not insured & 0.79 & $(0.60,1.07)$ & 0.125 \\
\hline \multicolumn{4}{|l|}{ Citizenship Status } \\
\hline US-born citizen (ref.) & --- & --- & \\
\hline Naturalized citizen & 0.85 & $(0.71,1.03)$ & 0.146 \\
\hline Non-Citizen & 0.82 & $(0.66,1.01)$ & 0.066 \\
\hline \multicolumn{4}{|l|}{ Survey year } \\
\hline $2001-2002$ (ref) & --- & --- & \\
\hline
\end{tabular}


Table 2 Logistic Regression for asthma diagnosis $(n=61,625)$ (Continued)

\begin{tabular}{|c|c|c|c|}
\hline & \multicolumn{2}{|c|}{ Doctor Ever Told you Your Child has Asthma } & \multirow[b]{2}{*}{$P$-value } \\
\hline & OR & $95 \% \mathrm{Cl}$ & \\
\hline 2003-2004 & 1.11 & $(0.99,1.25)$ & 0.075 \\
\hline $2005-2006$ & 1.09 & $(0.97,1.23)$ & 0.128 \\
\hline $2007-2008$ & 1.08 & $(0.96,1.22)$ & 0.187 \\
\hline 2009-2010 & 0.89 & $(0.78,1.02)$ & 0.109 \\
\hline $2011-2012$ & 1.12 & $(0.97,1.31)$ & 0.108 \\
\hline 2013 & 1.05 & $(0.85,1.30)$ & 0.664 \\
\hline 2014 & 0.89 & $(0.69,1.16)$ & 0.393 \\
\hline 2015 & 0.85 & $(0.62,1.18)$ & 0.338 \\
\hline
\end{tabular}

OR Odds Ratio, $\mathrm{Cl}$ Confidence Interval

${ }^{*} p<0.05$, ** $p<0.01,{ }^{* * *} p<0.001$

outcome analyses were conducted only for children diagnosed with asthma. All analyses used survey-specific routines to account for the complex sampling design for each survey year. This research was considered exempt from university IRB approval due to the de-identified nature of the public use data.

\section{Results}

As seen in Table 1, there were 61,625 completed surveys, representing an estimated annual population of 5.7 million children between 2001 and 2015. Of these, $12.9 \%$ reported having asthma at the time of survey. There were significant differences $(p<0.001)$ for child's age, gender, race, and parent's education, citizenship status, and English language proficiency. Asthma prevalence was higher among children 6 to 11 years of age (15.5\%), males (15.3\%), African Americans (19.5\%) and those of two or more races (13.7\%), children whose parents were a high school graduate $(13.4 \%)$, had some college $(16.1 \%)$, who spoke English very well (14.1\%), or was a US-born citizen (14.2\%). Prevalence was lowest among whites $(12 \%)$ and those with no usual source of care $(7.4 \%)$. There were also significant differences based on usual source of care $(p=0.0045)$, with higher prevalence among those normally receiving care at a doctor's office/HMO/Kaiser (13.3\%) and insurance $(p=$ 0.022 ), with higher prevalence among the insured $(13.0 \%)$. There were not significant differences based on poverty level, rural/urban status, or survey year.

As seen in Table 2, many of these findings identified in bivariate comparisons were confirmed in regression analysis. Particularly significant findings for age, gender, race, and English language proficiency and nonsignificant findings for survey year. Changes in regression included insurance and citizen status becoming statistically insignificant. However, there were now significantly lower likelihoods of having an asthma diagnosis for those at or above $200 \%$ of federal poverty level and for those living in a rural environment (odds ratio 0.85 ; $95 \%$ CI $0.74-0.99$ ). A nuance for parental education was that children whose parents had a high school degree were not significantly more likely to have asthma, only those whose parents had some college.

Table 3 presents results for four measures of asthma management. The most notable finding is that parental language proficience was significantly associated with three of the outcomes. Compared to those with English language proficiency of very well, both those with proficience of fairly well and not well/not at all were less likely to be taking daily medications to control asthma and to have been given an asthma management plan by a doctor, and the parents were more likely to not be confident that they could not control asthma.

With regards to other covariates, gender, rural/urban, insurance, and citizenship status were not significantly associated with any asthma management measure. Race (Asian and white less likely), poverty (less likely if not below $100 \% \mathrm{FPL}$ ), source of care (those with no usual source and those seen in government clinic/community hospital less likely), and survey year (decrease over time) were significantly associated with daily use of asthma medication. Age (older children less likely), parent's eduation (college graduates more likely), source of care (no usual source less likely), and survey year (increase over time) were significantly associated with doctor ever gave an asthma management for child. Parent's education (college more likely) and source of care (ER/urgent care less likely) were significantly associated with parent currently having a written copy of asthma management plan. No other measure besides adult language proficiency was significantly associated with confidence to control asthma.

Table 4 presents results of three asthma outcome measures. English language proficiency was significantly associated with two of the measures: children whose parent's were able to speak fairly were more likely to have an emergency room visit in past 12 months and to 
Table 3 Logistic Regression for Asthma Management

\begin{tabular}{|c|c|c|c|c|}
\hline & $\begin{array}{l}\text { Currently Taking Daily } \\
\text { Medication to Control Asthma } \\
n=6,669 \\
32,6 \%(30.84,4)\end{array}$ & $\begin{array}{l}\text { Doctor Ever Given Asthma } \\
\text { Management Plan for Child } \\
n=6,117\end{array}$ & $\begin{array}{l}\text { Have Written } \\
\text { Copy of Plan } \\
n=2,026 \\
32,3 \%(28.136 .5)\end{array}$ & $\begin{array}{l}\text { Not Confident can } \\
\text { Control Asthma } \\
n=2,836\end{array}$ \\
\hline Proportion & $32.6 \%(30.8,34.4)$ & $60.3 \%(57.5,63.2)$ & $32.3 \%(28.1,36.5)$ & $27.2 \%(23.1,31.4)$ \\
\hline \multicolumn{5}{|l|}{ Age } \\
\hline 1 to 5 years (ref.) & --- & -- & --- & --- \\
\hline 6 to 11 years & $0.74(0.62,0.89)^{* *}$ & $0.91(0.73,1.14)$ & $0.71(0.47,1.08)$ & $0.72(0.48,1.10)$ \\
\hline \multicolumn{5}{|l|}{ Gender } \\
\hline Male (ref.) & --- & --- & --- & --- \\
\hline Female & $0.85(0.72,1.02)$ & $1.04(0.80,1.34)$ & $1.28(0.85,1.93)$ & $1.06(0.68,1.63)$ \\
\hline \multicolumn{5}{|l|}{ Race/ethnicity } \\
\hline Hispanic (ref.) & --- & --- & --- & --- \\
\hline Asian & $0.57(0.39,0.82)^{* *}$ & $0.76(0.47,1.22)$ & $0.86(0.44,1.69)$ & $0.53(0.21,1.32)$ \\
\hline African American & $0.98(0.71,1.36)$ & $0.84(0.54,1.32)$ & $1.10(0.52,2.33)$ & $1.45(0.69,3.02)$ \\
\hline White & $0.65(0.51,0.83)^{* *}$ & $0.88(0.63,1.23)$ & $1.26(0.73,2.17)$ & $0.91(0.54,1.56)$ \\
\hline Two or more Races & $0.90(0.59,1.38)$ & $0.62(0.38,1.03)$ & $1.11(0.49,2.51)$ & $0.70(0.35,1.42)$ \\
\hline \multicolumn{5}{|l|}{ Adult English Proficiency } \\
\hline Very well (ref.) & --- & --- & --- & --- \\
\hline Fairly well & $0.63(0.45,0.87)^{* *}$ & $0.45(0.25,0.80)^{* *}$ & $0.54(0.23,1.24)$ & $3.39(1.52,7.54)^{* *}$ \\
\hline Not well / Not at all & $0.52(0.36,0.74)^{* * *}$ & $0.30(0.20,0.46)^{* * *}$ & $1.34(0.58,3.12)$ & $3.10(1.49,6.42)^{* *}$ \\
\hline \multicolumn{5}{|l|}{ Adult Education } \\
\hline Less than 12 years (ref) & -- & --- & --- & --- \\
\hline High School graduate & $1.13(0.85,1.52)$ & $1.25(0.82,1.92)$ & $1.55(0.75,3.21)$ & $1.07(0.52,2.22)$ \\
\hline Some college & $0.94(0.69,1.27)$ & $1.33(0.84,2.11)$ & $2.33(1.07,5.08)^{*}$ & $1.03(0.45,2.34)$ \\
\hline $\begin{array}{l}\text { College graduate or } \\
\text { higher }\end{array}$ & $0.93(0.68,1.27)$ & $1.94(1.25,3.02)^{*}$ & $3.21(1.35,7.64)^{* *}$ & $0.95(0.43,2.08)$ \\
\hline \multicolumn{5}{|l|}{ Poverty level } \\
\hline 0-99\% FPL (ref.) & --- & --- & --- & --- \\
\hline 100-199\% FPL & $0.73(0.56,0.96)^{*}$ & $1.04(0.70,1.53)$ & $0.98(0.54,1.78)$ & $0.58(0.32,1.08)$ \\
\hline 200-299\% FPL & $0.72(0.51,1.03)$ & $0.99(0.55,1.77)$ & $1.02(0.51,2.01)$ & $1.43(0.58,3.50)$ \\
\hline 300\% FPL and Above & $0.63(0.47,0.85)^{* *}$ & $1.03(0.67,1.58)$ & $0.62(0.33,1.17)$ & $0.89(0.44,1.81)$ \\
\hline \multicolumn{5}{|l|}{ Residence } \\
\hline Urban (ref.) & --- & --- & --- & --- \\
\hline Rural & $1.12(0.87,1.45)$ & $1.15(0.83,1.58)$ & $1.03(0.58,1.84)$ & $1.23(0.63,2.41)$ \\
\hline \multicolumn{5}{|l|}{ Usual Source of Care } \\
\hline Office/HMO/Kaiser (ref.) & --- & --- & --- & --- \\
\hline $\begin{array}{l}\text { Government clinic / } \\
\text { Community hospital }\end{array}$ & $0.75(0.61,0.92)^{* *}$ & $0.99(0.72,1.38)$ & $1.64(0.93,2.91)$ & $0.98(0.60,1.58)$ \\
\hline $\begin{array}{l}\text { ER/Urgent care/ Other } \\
\text { place }\end{array}$ & $0.54(0.26,1.12)$ & $1.26(0.63,2.55)$ & $0.11(0.02,0.50)^{* *}$ & $0.54(0.10,2.84)$ \\
\hline No usual source of care & $0.48(0.24,0.98)^{*}$ & $0.30(0.12,0.74)^{*}$ & $1.75(0.25,12.08)$ & $1.54(0.36,6.60)$ \\
\hline \multicolumn{5}{|l|}{ Insurance status } \\
\hline Insured (ref.) & --- & --- & --- & --- \\
\hline Not insured & $0.86(0.56,1.31)$ & $0.88(0.53,1.49)$ & $2.25(0.36,14.11)$ & $0.61(0.20,1.86)$ \\
\hline \multicolumn{5}{|l|}{ Citizenship Status } \\
\hline US-born citizen (ref.)ta & --- & --- & --- & --- \\
\hline Naturalized citizen & $1.10(0.83,1.46)$ & $1.10(0.73,1.67)$ & $1.73(0.92,3.26)$ & $1.20(0.65,2.21)$ \\
\hline
\end{tabular}


Table 3 Logistic Regression for Asthma Management (Continued)

\begin{tabular}{|c|c|c|c|c|}
\hline & $\begin{array}{l}\text { Currently Taking Daily } \\
\text { Medication to Control Asthma } \\
n=6,669\end{array}$ & $\begin{array}{l}\text { Doctor Ever Given Asthma } \\
\text { Management Plan for Child } \\
n=6,117\end{array}$ & $\begin{array}{l}\text { Have Written } \\
\text { Copy of Plan } \\
n=2,026\end{array}$ & $\begin{array}{l}\text { Not Confident can } \\
\text { Control Asthma } \\
n=2,836\end{array}$ \\
\hline Proportion & $32.6 \%(30.8,34.4)$ & $60.3 \%(57.5,63.2)$ & $32.3 \%(28.1,36.5)$ & $27.2 \%(23.1,31.4)$ \\
\hline Non-Citizen & $1.23(0.91,1.67)$ & $1.48(0.90,2.44)$ & $1.27(0.58,2.36)$ & $1.45(0.69,3.05)$ \\
\hline \multicolumn{5}{|l|}{ Survey year } \\
\hline $2001-2002$ & REF & N/A & N/A & NA \\
\hline $2003-2004$ & $0.58(0.46,0.75)^{* * *}$ & REF & N/A & N/A \\
\hline $2005-2006$ & $0.37(0.29,0.48)^{* * *}$ & $1.01(0.78,1.30)$ & N/A & N/A \\
\hline $2007-2008$ & $0.39(0.30,0.51)^{* * *}$ & $0.98(0.77,1.24)$ & N/A & N/A \\
\hline $2009-2010$ & $0.50(0.38,0.66)^{* * *}$ & $2.74(2.13,3.52)^{* * *}$ & REF & REF \\
\hline $2011-2012$ & $0.38(0.28,0.53)^{* * *}$ & $3.42(2.47,4.73)^{* * *}$ & $1.32(0.90,1.96)$ & $0.81(0.53,1.23)$ \\
\hline 2013 & N/A & $2.78(1.57,4.92)^{* * *}$ & $0.99(0.61,1.62)$ & $0.87(0.51,1.49)$ \\
\hline 2014 & N/A & N/A & $1.84(1.13,2.98)^{*}$ & $0.93(0.53,1.64)$ \\
\hline 2015 & N/A & $2.16(1.08,4.34)^{*}$ & $1.35(0.64,2.82)$ & $0.74(0.34,1.65)$ \\
\hline
\end{tabular}

${ }^{*} p<0.05,{ }^{* *} p<0.01,{ }^{* * *} p<0.001$

N/A-question not asked during that survey year

have missed school in past 12 months due to asthma. Many variables were not statistically significant with any outcome: gender, poverty, living environment, insurance, and citizenship status. Children 6-11 years of age were less likely to have any of all three outcomes. African Americans were more likely to have an emergeny room visit. Children whose parents had some college were more likely to have an asthma attack in the past 12 months. Emergency room visits were generally lower over time.

\section{Discussion}

These findings suggest that among California children 1 to 11 years of age, risk of asthma is higher among African Americans and lower for non-Hispanic Whites. Furthermore, asthma risk is higher among boys and older children. Diagnosis is also greater among those whose parents spoke English very well. The likelihood of diagnosis is lower among those with higher income, for children having no usual source of medical care, and for those living in a rural environment [32].

Across the seven asthma management and outcome measures in this study, parent English language proficiency was significantly associated with five of the measures. The consistent finding being that those with lower levels of proficiency were more likely to have the less desirable outcome. Usual source of care was also associated with five measures. Regarding socio-demographics, age was significantly associated with four measures, as was survey year. Parent education was significantly associated with three measures, race/ethnicity with two measures, and poverty level with one measure. Gender, rural/urban, insurance, and citizenship were not significantly associated with any measure.
For children diagnosed with asthma, those whose parents spoke English very well were more likely to have routine management measures, such as receipt of a written plan and daily medications and were less likely to have an emergency room visit in the past 12 months or to miss school due to asthma. Their parents were also much more likely to feel confident they could control asthma. Information plays a large role in controlling a chronic disease. Unfortunately prior analysis with CHIS data has shown that many California parents having children with asthma have suboptimal use of health literacy tools [17] and Latino adults with limited English proficiency report less confidence in filling out online forms [33]. Furthermore, a study outside of California found that parents with limited health literacy were more likely to have children whose asthma was not well controlled [34].

Others have found that asthma is a public health concern affecting minority groups and low-income children [35]. This study did not find an association between income and asthma management/outcome. This appears to be inconsistent with a study based on northern California Kaiser Permanente patients which found that lower-income parents who had higher cost-sharing were more likely to delay or avoid asthma care for their young children [36]. However, we were not able to evaluate delay in care or quality of medical care, other than giving an asthma management plan. The impact of poverty was most likely observed through usual source of care. Typically it is parents with steady jobs and/or higher income who can afford regular care at a doctor's office. Being seen consistently in such a setting is associated with better care [37] and also is more likely to result in care through a medical home model [38] and to be following the latest treatment guidelines [39]. 
Table 4 Logistic Regression for Asthma Outcomes

\begin{tabular}{|c|c|c|c|}
\hline & $\begin{array}{l}\text { Had Asthma Attack In Past } 12 \\
\text { Months }\end{array}$ & $\begin{array}{l}\text { Emergency Room visit in past } 12 \\
\text { months }\end{array}$ & $\begin{array}{l}\text { Missed School due to Asthma in Past } \\
12 \text { Months }\end{array}$ \\
\hline & $n=5,514$ & $n=5,339$ & $n=6,435$ \\
\hline Proportion & $45.2 \%(43.0,47.4)$ & $30.9 \%(28.0,33.8)$ & $32.8 \%(30.4,35.2)$ \\
\hline \multicolumn{4}{|l|}{ Age } \\
\hline 1 to 5 years (ref.) & --- & --- & --- \\
\hline 6 to 11 years & $0.62(0.51,0.74)^{* * *}$ & $0.44(0.33,0.57)^{* * *}$ & $0.79(0.63,0.99)^{*}$ \\
\hline \multicolumn{4}{|l|}{ Gender } \\
\hline Male (ref.) & --- & --- & --- \\
\hline Female & $0.90(0.76,1.07)$ & $1.02(0.74,1.43)$ & $1.08(0.84,1.39)$ \\
\hline \multicolumn{4}{|l|}{ Race/ethnicity } \\
\hline Hispanic (ref.) & --- & --- & --- \\
\hline Asian & $0.94(0.63,1.40)$ & $0.62(0.36,1.07)$ & $0.71(0.45,1.12)$ \\
\hline African American & $0.95(0.65,1.40)$ & $2.10(1.24,3.55)^{* *}$ & $1.55(0.95,2.52)$ \\
\hline White & $1.14(0.88,1.49)$ & $0.99(0.70,1.41)$ & $0.75(0.54,1.04)$ \\
\hline Two or more Races & $0.94(0.62,1.42)$ & $0.97(0.55,1.72)$ & $0.65(0.40,1.06)$ \\
\hline \multicolumn{4}{|l|}{ Adult English Proficiency } \\
\hline Very well (ref.) & --- & --- & --- \\
\hline Fairly well & $0.86(0.60,1.24)$ & $1.92(1.03,3.61)^{*}$ & $1.73(1.01,2.94)^{*}$ \\
\hline Not well / Not at all & $0.74(0.51,1.07)$ & $0.89(0.51,1.55)$ & $1.08(0.69,1.70)$ \\
\hline \multicolumn{4}{|l|}{ Adult Education } \\
\hline Less than 12 years (ref.) & --- & --- & --- \\
\hline High school graduate & $1.16(0.83,1.64)$ & $1.30(0.73,2.28)$ & $0.90(0.61,1.34)$ \\
\hline Some college & $1.42(1.01,1.98)^{*}$ & $1.52(0.91,2.53)$ & $0.83(0.56,1.23)$ \\
\hline College graduate or higher & $1.33(0.93,1.90)$ & $1.06(0.62,1.78)$ & $0.71(0.46,1.08)$ \\
\hline \multicolumn{4}{|l|}{ Poverty level } \\
\hline 0-99\% FPL (ref.) & --- & --- & --- \\
\hline 100-199\% FPL & $1.04(0.80,1.34)$ & $0.84(0.48,1.46)$ & $1.07(0.71,1.60)$ \\
\hline 200-299\% FPL & $1.18(0.83,1.68)$ & $0.79(0.45,1.38)$ & $1.32(0.79,2.21)$ \\
\hline $300 \% \mathrm{FPL}$ and Above & $1.18(0.88,1.59)$ & $0.86(0.55,1.33)$ & $1.07(0.71,1.64)$ \\
\hline \multicolumn{4}{|l|}{ Living environment } \\
\hline Urban (ref.) & --- & --- & --- \\
\hline Rural & $1.24(0.97,1.58)$ & $1.38(0.92,2.07)$ & $1.04(0.75,1.44)$ \\
\hline \multicolumn{4}{|l|}{ Usual Source of Care } \\
\hline Office/HMO/Kaiser (ref.) & --- & --- & --- \\
\hline $\begin{array}{l}\text { Government clinic / Community } \\
\text { hospital }\end{array}$ & $0.86(0.71,1.06)$ & $0.98(0.67,1.44)$ & $0.91(0.68,1.21)$ \\
\hline ER/Urgent care/ Other & $0.39(0.19,0.78)^{* *}$ & $2.80(1.27,6.17)^{*}$ & $0.69(0.30,1.57)$ \\
\hline No usual source of care & $0.60(0.32,1.12)$ & $1.16(0.41,3.22)$ & $0.66(0.27,1.62)$ \\
\hline \multicolumn{4}{|l|}{ Insurance status } \\
\hline Insured (ref.) & --- & --- & --- \\
\hline Not insured & $0.83(0.51,1.36)$ & $0.64(0.38,1.06)$ & $0.88(0.41,1.88)$ \\
\hline \multicolumn{4}{|l|}{ Citizenship Status } \\
\hline US-born citizen (ref.) & --- & --- & --- \\
\hline Naturalized citizen & $1.16(0.84,1.60)$ & $1.08(0.70,1.73)$ & $0.88(0.60,1.31)$ \\
\hline Non-Citizen & $0.91(0.65,1.26)$ & $1.22(0.73,2.05)$ & $0.82(0.53,1.27)$ \\
\hline
\end{tabular}


Table 4 Logistic Regression for Asthma Outcomes (Continued)

\begin{tabular}{|c|c|c|c|}
\hline & $\begin{array}{l}\text { Had Asthma Attack In Past } 12 \\
\text { Months }\end{array}$ & $\begin{array}{l}\text { Emergency Room visit in past } 12 \\
\text { months }\end{array}$ & $\begin{array}{l}\text { Missed School due to Asthma in Past } \\
12 \text { Months }\end{array}$ \\
\hline & $n=5,514$ & $n=5,339$ & $n=6,435$ \\
\hline Proportion & $45.2 \%(43.0,47.4)$ & $30.9 \%(28.0,33.8)$ & $32.8 \%(30.4,35.2)$ \\
\hline \multicolumn{4}{|l|}{ Survey year } \\
\hline $2001-2002$ & N/A & N/A & N/A \\
\hline $2003-2004$ & REF & N/A & REF \\
\hline $2005-2006$ & $1.06(0.86,1.32)$ & REF & $1.14(0.91,1.43)$ \\
\hline $2007-2008$ & $0.91(0.71,1.16)$ & $0.75(0.58,0.98)^{*}$ & $1.05(0.81,1.35)$ \\
\hline $2009-2010$ & $0.93(0.72,1.19)$ & $0.56(0.42,0.73)^{* * *}$ & $1.14(0.87,1.50)$ \\
\hline $2011-2012$ & $0.91(0.66,1.25)$ & $0.99(0.70,1.39)$ & $1.05(0.77,1.44)$ \\
\hline 2013 & N/A & $0.70(0.44,1.13)$ & $1.38(0.84,2.26)$ \\
\hline 2014 & N/A & $0.36(0.19,0.65)^{* *}$ & $0.97(0.61,1.52)$ \\
\hline 2015 & N/A & $0.98(0.48,2.01)$ & $1.35(0.79,2.31)$ \\
\hline
\end{tabular}

N/A Not available (question not asked during survey year)

${ }^{*} p<0.05,{ }^{* *} p<0.01,{ }^{* * *} p<0.001$

The higher rates among children in California compared to the United States as a whole [2] may reflect higher actual prevalence or suggest that perhaps better assessment and screening of asthma at the national level is necessary. The finding of higher asthma prevalence among boys and African Americans is also consistent with national data [2], as is the higher prevalence of those with two or more races [3]. California, due to its SCHIP (State Children's Health Insurance Plan) which is primarily targeted towards immigrant minorities, could be one the reason for better diagnosis compared to national numbers [40]. Findings for Asians were also compable to national data by being similar to whites. Some study suggests higher rates of asthma of among Asian immigrants [41]; but any such effect in California is likely overcome by the dramatically lower likelihood of asthma among immigrants to the US. Others have found that minority children are more likely to have increased emergency visits, hospitalization and death from asthma [42], though we only found higher rates of emergency room visits for African Americans.

Thirty-six thousand students miss school every day because of asthma. Students having persistent asthma tend to show increased absenteeism and lower performances in standardized tests [42]. Therefore, school-based asthma education and management can be a potential asthma intervention [43]. Such programs should especially target and be tailored to families having limited English proficiency.

The prevalence of asthma seems to be lower among those of Mexican descent. However, this can be as a result of under diagnosis [44]. Limited English proficiency is another burden on some Hispanic families as they suffer poorer quality of care due to communication errors
[45]. It is possible that low acculturation is not protective against asthma but that immigrants with little English proficiency are less likely to understand their physician or asthma symptoms, and thus report lower diagnosis rates [46]. In turn, this can overlook a critically underserved population, highlighting the need for culturally and linguistically tailored preventive measures. As such, there should be additional public health efforts aimed at mitigating the current unmet asthma prevention and management care needs [47] for all families with limited English proficiency, particularlyLatinos. For example, delivery of health literacy interventions for caregivers of asthmatic children through culturally and linguistically competent clinicians could be of value [20].

\section{Limitations}

The primary limitation of the study stems from its cross-sectional self-reported design. Such study designs do not provide insight into causation and therefore relative risks of outcomes cannot be evaluated. Moreover, self-reported data is prone to recall bias. Due to the cross-sectional nature of the survey, we were not able to formally test whether better management activities caused better outcomes. Our measure for ED visits was for all causes, not only asthma-related. Another limitation is selection bias, especially for families who do not have phones. Furthermore, results may not be generalizable outside of California. Despite such limitations, our findings have several strengths. The CHIS study was designed specifically to assess the health of Californians. In addition to the well-established sampling design, surveys are thorough in addressing child and family factors. Furthermore, the relatively large sample size allows for stable estimates. 


\section{Conclusions}

This large, population-based survey demonstrated that the English language proficiency of parents/caretakers had a stronger and more consistent effect on a group of asthma management measures than did health insurance, family income, and parental education. This highlights the importance of providing care and health education in a linguistically-appropriate manner for the most common chronic medical condition in children.

\section{Acknowledgements}

Not applicable.

\section{Authors' contributions}

JEB and NM conceptualized the study. JEB obtained the data and MR performed statistical analysis. JEB drafted initial manuscript and NM, MR, NA, and KA did additional writing and editing. All authors read and approved the final manuscript.

\section{Funding}

Not applicable.

\section{Availability of data and materials}

The public-use data files are available from the University of California, Los Angeles, and were obtained through the following link: https://healthpolicy. ucla.edu/chis/data/Pages/public-use-data.aspx.

\section{Declarations}

\section{Ethics approval and consent to participate}

This study of public-use data was deemed exempt from IRB approval. Informed consent was obtained from all individual participants during the data collection process.

\section{Consent for publication}

Not Applicable.

\section{Competing interests}

Not applicable.

\section{Author details}

${ }^{1}$ Loma Linda University School of Public Health, 24951 Circle Dr, CA 92354 Loma Linda, USA. ${ }^{2}$ College of Medicine, Alfaisal University, 7746 Ibrahim Alziady St., Alwurud District, 122532499 Riyadh, Saudi Arabia.

Received: 5 October 2020 Accepted: 4 May 2021

Published online: 27 May 2021

\section{References}

1. Sullivan PW, Ghushchyan V, Navaratnam P, Friedman HS, Kavati A, Ortiz B, et al. The national burden of poorly controlled asthma, school absence and parental work loss among school-aged children in the United States. J Asthma. 2018;55(6):659-67.

2. Zahran HS, Bailey CM, Damon SA, Garbe PL, Breysse PN. Vital Signs: Asthma in Children - United States, 2001-2016. MMWR Morb Mortal Wkly Rep. 2018; 67(5):149-55.

3. Wen C, Liu SH, Li Y, Sheffield P, Liu B. Pediatric Asthma Among Small Racial/ Ethnic Minority Groups: An Analysis of the 2006-2015 National Health Interview Survey. Public Health Rep. 2019;134(4):338-43.

4. Sundbom F, Malinovschi A, Lindberg E, Alving K, Janson C. Effects of poor asthma control, insomnia, anxiety and depression on quality of life in young asthmatics. J Asthma. 2016;53(4):398-403.

5. Scotney E, Saglani S. Diagnosis and Management of Problematic Severe Asthma. Acta Med Acad. 2020;49(2):117-29.

6. Jackson DJ, Sykes A, Mallia P, Johnston SL. Asthma exacerbations: origin effect, and prevention. J Allergy Clin Immunol. 2011;128(6):1165-74.

7. Hsu J, Qin X, Beavers SF, Mirabelli MC. Asthma-Related School Absenteeism, Morbidity, and Modifiable Factors. Am J Prev Med. 2016;51(1):23-32.
8. Al-Muhsen S, Horanieh N, Dulgom S, Aseri ZA, Vazquez-Tello A, Halwani R, et al. Poor asthma education and medication compliance are associated with increased emergency department visits by asthmatic children. Ann Thorac Med. 2015;10(2):123-31.

9. Sullivan PW, Ghushchyan V, Navaratnam P, Friedman HS, Kavati A, Ortiz B, et al. The national cost of asthma among school-aged children in the United States. Ann Allerg Asthma Im. 2017;119(3):246-52. e1.

10. Ochoa-Aviles C, Morillo D, Rodriguez A, Cooper PJ, Andrade S, Molina M, et al. Prevalence and risk factors for asthma, rhinitis, eczema, and atopy among preschool children in an Andean city. PLoS One. 2020;15(7): e0234633.

11. Papi A, Brightling C, Pedersen SE, Reddel HK. Asthma. The Lancet. 2018; 391(10122):783-800.

12. Ripabelli G, Tamburro M, Sammarco ML, de Laurentiis G, Bianco A. Asthma prevalence and risk factors among children and adolescents living around an industrial area: a cross-sectional study. BMC Public Health. 2013;13(1):1038.

13. Rosser FJ, Forno E, Cooper PJ, Celedon JC. Asthma in Hispanics. An 8-year update. Am J Resp Crit Care. 2014;189(11):1316-27.

14. Akinbami LJ, Moorman JE, Bailey C, Zahran HS, King M, Johnson CA, et al. Trends in asthma prevalence, health care use, and mortality in the United States, 2001-2010. NCHS Data Brief. 2012(94):1-8.

15. Sack CS, Goss CH. Nature versus Nurture: Does Genetic Ancestry Alter the Effect of Air Pollution in Children with Asthma?: Am Thoracic Soc; 2016.

16. Northridge J, Ramirez OF, Stingone JA, Claudio L. The role of housing type and housing quality in urban children with asthma. J Urban Health. 2010; 87(2):211-24.

17. Shaikh U, Byrd RS. Population Health Considerations for Pediatric Asthma: Findings from the 2011-2012 California Health Interview Survey. Popul Health Manag. 2016;19(2):145-51.

18. Canino G, Garro A, Alvarez MM, Colon-Semidey A, Esteban C, Fritz G, et al. Factors associated with disparities in emergency department use among Latino children with asthma. Ann Allerg Asthma Im. 2012;108(4): 266-70

19. Stewart KA, Higgins PC, McLaughlin CG, Williams TV, Granger E, Croghan TW. Differences in prevalence, treatment, and outcomes of asthma among a diverse population of children with equal access to care: findings from a study in the military health system. Arch Pediatr Adolesc Med. 2010;164(8): 720-6.

20. Holsey CN, Collins P, Zahran H. Disparities in asthma care, management, and education among children with asthma. Clinical pulmonary medicine. 2013;20(4):172.

21. Martin MA, Press VG, Nyenhuis SM, Krishnan JA, Erwin K, Mosnaim G, et al. Care transition interventions for children with asthma in the emergency department. J Allergy Clin Immunol. 2016;138(6):1518-25.

22. Carrillo G, Perez-Patron MJ, Lucio RL, Cabrera L, Trevino A, Xu X, et al. The Benefits and Challenges of Managing Asthma in Hispanic Families in South Texas: A Mixed-Methods Study. Front Public Health. 2017:5:150.

23. Tull RZ, Feldman SR. Cultural Considerations. Dermatoanthropology of Ethnic Skin and Hair: Springer; 2017. p. 467 - 77

24. UCLA Center for Health Policy and Research. California Health Interview Survey: Overview 2018 [Available from: http://healthpolicy.ucla.edu/chis/a bout/Pages/about.aspx.

25. Ponce NA, Lavarreda SA, Yen W, Brown ER, DiSogra C, Satter DE. The California Health Interview Survey 2001: translation of a major survey for California's multiethnic population. Public Health Rep. 2004;119(4):388-95.

26. California Health Interview Survey. What's New and Notable in CHIS 2015. UCLA Center for Health Policy Research; 2016.

27. California health interview survey. CHIS 2009 methodology series: Report Response rates. Los Angeles, CA: UCLA Center for Health Policy Research; 2011

28. California Health Interview Survey. CHIS 2015-2016 Methodology Series: Report 5 - Weighting and Variance Estimation. Los Angeles: UCLA Center for Health Policy Research; 2017.

29. Epstein JA, Botvin GJ, Dusenbury L, Diaz T, Kerner J. Validation of an acculturation measure for Hispanic adolescents. Psychol Rep. 1996;79(3 Pt 1):1075-9.

30. Lu T, Myerson R. Disparities in Health Insurance Coverage and Access to Care by English Language Proficiency in the USA, 2006-2016. J Gen Intern Med. 2020;35(5):1490-7.

31. Survey CHI. CHIS 2013-2014 Methodology Series: Report 5 - Weighting and Variance Estimation. Los Angeles. CA: UCLA Center for Health Policy Research;2016.. 
32. Estrada RD, Ownby DR. Rural Asthma: Current Understanding of Prevalence, Patterns, and Interventions for Children and Adolescents. Curr Allergy Asthma Rep. 2017;17(6):37.

33. Gonzalez M, Sanders-Jackson A, Emory J. Online Health Information-Seeking Behavior and Confidence in Filling Out Online Forms Among Latinos: A Cross-Sectional Analysis of the California Health Interview Survey, 20112012. J Med Internet Res. 2016;18(7):e184.

34. Krishnan S, Rohman A, Welter J, Dozor AJ. Relationship Between Health Literacy in Parents and Asthma Control in Their Children: A Prospective Study in a Diverse Suburban Population. Pediatric Allergy Immunology Pulmonology. 2018;31(4):221-5.

35. Callaghan-Koru J, Riekert KA, Ruvalcaba E, Rand CS, Eakin MN. Medication beliefs are associated with not having controller medications available among head start children with asthma. B23 NOVEL EPIDEMIOLOGY, MANAGEMENT, AND OUTCOMES IN ASTHMA: American Thoracic Society; 2017. p. A2991-A.

36. Fung V, Graetz I, Galbraith A, Hamity C, Huang J, Vollmer WM, et al. Financial barriers to care among low-income children with asthma: health care reform implications. JAMA Pediatr. 2014;168(7):649-56.

37. Crain EF, Kercsmar C, Weiss KB, Mitchell H, Lynn H. Reported Difficulties in Access to Quality Care for Children With Asthma in the Inner City. Arch Pediatr Adolesc Med. 1998;152(4):333-9.

38. Rojanasarot S, Carlson AM. The Medical Home Model and Pediatric Asthma Symptom Severity: Evidence from a National Health Survey. Popul Health Manag. 2018;21(2):130-8.

39. Tesse R, Borrelli G, Mongelli G, Mastrorilli V, Cardinale F. Treating Pediatric Asthma According Guidelines. Front Pediatr. 2018;6:234.

40. Paradise J. The Impact of the Children's Health Insurance Program (CHIP): What Does the Research Tell. Us?: Kaiser Family Foundation; 2014.

41. Suaini NHA, Koplin JJ, Peters RL, Sasaki M, Ellis JA, Martino DJ, et al. Children with East Asian-Born Parents Have an Increased Risk of Allergy but May Not Have More Asthma in Early Childhood. J Allergy Clin Immunol Pract. 2019; 7(2):539-47. e3.

42. Liptzin DR, Gleason MC, Cicutto LC, Cleveland CL, Shocks DJ, White MK, et al. Developing, Implementing, and Evaluating a School-Centered Asthma Program: Step-Up Asthma Program. J Allergy Clin Immunol Pract. 2016;4(5): 972-9 e1.

43. Meng YY, Babey SH, Wolstein J. Asthma-related school absenteeism and school concentration of low-income students in California. Prev Chronic Dis, 2012;9:E98.

44. Siañez M, Highfield L, Balcazar H, Collins T, Grineski S. An Examination of the Association of Multiple Acculturation Measures with Asthma Status Among Elementary School Students in El Paso, Texas. Journal of immigrant and minority health. 2017:1-10.

45. Napoles AM, Santoyo-Olsson J, Karliner LS, Gregorich SE, Perez-Stable EJ. Inaccurate Language Interpretation and Its Clinical Significance in the Medical Encounters of Spanish-speaking Latinos. Med Care. 2015;53(11):940-7.

46. Milet M. Asthma in California: A Surveillance Report. In: Branch EHI, editor. Richmond: California Department of Public Health; 2017.

47. Caminati M, Vaia R, Furci F, Guarnieri G, Senna G. Uncontrolled Asthma: Unmet Needs in the Management of Patients. J Asthma Allergy. 2021;14 457-66.

Ready to submit your research? Choose BMC and benefit from:

- fast, convenient online submission

- thorough peer review by experienced researchers in your field

- rapid publication on acceptance

- support for research data, including large and complex data types

- gold Open Access which fosters wider collaboration and increased citations

- maximum visibility for your research: over $100 \mathrm{M}$ website views per year

At BMC, research is always in progress.

Learn more biomedcentral.com/submissions 